\title{
UMA ANÁLISE DA JURISPRUDÊNCIA DO SUPREMO TRIBUNAL FEDERAL SOBRE EXTRADIÇÃO: O BRASIL NÃO É O PARAÍSO PARA OS CRIMINOSOS ESTRANGEIROS
}

\author{
An Analysis of Brazilian Supreme Federal Court Case-Law on \\ Extradition: Brazil is not a Safe Haven for Foreign Criminals ${ }^{1}$
}

\author{
Irene Bogado Diniz ${ }^{2}$ \\ Marcos Vinícus Torres Pereira 3
}

\begin{abstract}
Sumário: 1 Introdução. 2 Extradição, direito internacional e condição jurídica do estrangeiro. $3 \mathrm{O}$ instituto da extradição no Brasil. $4 \mathrm{~A}$ jurisprudência do Supremo Tribunal Federal sobre extradição. 5 Conclusão. Referências.
\end{abstract}

Resumo: Este artigo versa sobre o instituto da extradição e o tratamento conferido pelo Supremo Tribunal Federal, órgão judiciário competente para analisar a sua admissibilidade, com o objetivo de se desvendar ser o Brasil um país conivente com o refúgio de criminosos em seu território, conforme o imaginário cinematográfico, ou, um país que respeita os preceitos e tratados do Direito Internacional, mostrando-se como um Estado ativo no contexto da cooperação jurídica internacional. O método escolhido para esta pesquisa foi a coleta de dados a partir de acórdãos prolatados pela Suprema Corte no período compreendido entre o ano de 2000 ao de 2010, que foram devidamente condensados em gráficos que auxiliam a análise crítica.

Palavras-chave: Extradição; Jurisprudência; Supremo Tribunal Federal.

Abstract: This article is about the institute of extradition and its application by the Federal Supreme Court, the judicial court competent to analyze its admissibility, with the goal of uncovering whether Brazil is a country allied to the sheltering of criminals in its territory, as the cinematographic industry's depiction, or a country that respects treaties and norms established by International Law, showing itself as an active country in the context of international judicial cooperation. The method chosen to this research was the data collection from judgments rendered by the Supreme Court in the period comprehended between year 2000 and 2010, which were accordingly condensed in graphics which help the critical analysis.

Keywords: Extradition; Jurisprudence; Federal Supreme Court.

\section{INTRODUÇÃO}

“E então, fugiu para o Brasil...”.

Foi com expressões semelhantes a esta que a indústria cinematográfica incutiu e reproduziu uma imagem que deu fama ao Brasil de país não só repleto de belezas naturais, mas também de um verdadeiro paraíso para o refúgio seguro de criminosos. Embora, nos últimos anos, a política internacional do país nesta área tenha avançado significativamente, perdura a "reputação" como um país de

\footnotetext{
${ }^{1}$ DOI deste artigo: http://dx.doi.org/10.12957/cosmopolitan.2014.12375.

2 Bacharel em direito pela Universidade Federal do Rio de Janeiro.

3 Doutor em Direito Internacional e da Integração Econômica (UERJ). Professor Adjunto do Departamento de Direito Civil da Faculdade Nacional de Direito, da Universidade Federal do Rio de Janeiro (FND/UFRJ), onde leciona Direito Internacional Privado e Direito Civil.
} 
impunidades. Não obstante, já se pode notar uma gradual mudança deste estigma do Brasil no cenário internacional.

Essa opinião deturpada foi pautada, entre outros motivos, por casos como o de Ronald Biggs e de Cesare Battisti, que foram intensivamente explorados por uma mídia do espetáculo, auxiliada pela velocidade de informações. Deste modo, foi passada ao expectador inexperiente e desprevenido uma falsa imagem, através da emissão de dados viciados, comprometendo uma comunicação efetiva e afetando a opinião popular.

O intenso trânsito entre os países, propiciado pelos novos meios de transporte, possibilita, não só o aumento de crimes internacionais, como também a fuga de criminosos. Esta nova característica afeta, diretamente, o tratamento conferido pelo país à extradição, haja visto que nosso país é, muitas vezes, identificado como país de refúgio e impunidades, onde criminosos ou supostos criminosos estrangeiros poderiam se esconder, fugindo da persecução criminal ou do cumprimento de pena em país estrangeiro.

Através da análise, com dados quantitativos e qualitativos, da jurisprudência brasileira relativa à extradição no presente artigo, pretendemos demonstrar que tal ideia sobre o país é equivocada.

Como a extradição no Brasil é um procedimento que se divide em duas partes: judicial e administrativa, faz-se mister ressaltar que essa pesquisa tem enfoque direcionado à análise da atuação da nossa Egrégia Corte Suprema neste procedimento misto.

\section{EXTRADIÇÃO, DIREITO INTERNACIONAL E CONDIÇÃO JURÍDICA DO ESTRANGEIRO}

Alguns doutrinadores debatem se a extradição estaria no campo do Direito Internacional Público ou do Direito Internacional Privado. A matéria toca esta disciplina, cujo objeto4 abarcaria a nacionalidade, a condição jurídica do

\footnotetext{
4 Para a chamada Escola Francesa o conflito de jurisdições, juntamente com o conflito de leis, a nacionalidade e a condição jurídica do estrangeiro, compõe o objeto de estudo do Direito Internacional Privado. Muitos doutrinadores compartilham desta opinião no Brasil, como Haroldo Valladão e Clovis Bevilaqua. Outros doutrinadores preferem delinear o objeto do DIPRI, com outros termos. Henri Batiffol e Paul Lagarde falam em sujeitos do direito, exercício dos direitos e sanção dos direitos. Antoine Pillet se refere a gozo dos direitos, exercício dos direitos e reconhecimento dos direitos, dando também destaque à questão dos direitos adquiridos. No "Conflict of Laws" do "Common Law", o conflito de jurisdições é incluído no objeto do DIPRI juntamente com o conflito de leis. Mesmo no Direito Alemão que costumava restringir o objeto Revista de Direito Internacional do Programa de Pós-Graduação em Direito da UERJ 169
} 
estrangeiro, o conflito de leis e o conflito de jurisdições; já que a extradição constitui medida de saída compulsória de estrangeiro - apesar de também poder ser aplicada a brasileiro naturalizado - do Brasil, incluindo-se, ipso facto, na seara da condição jurídica do estrangeiro, que versa sobre direitos e deveres dos estrangeiros.

Simultaneamente, a extradição é um mecanismo de cooperação internacional entre os Estados, razão pela qual se inseriria sendo parte da matéria Condição Jurídica do Estrangeiro no Direito Internacional Público, por envolver questões políticas e diplomáticas entre Estados soberanos.

Debates doutrinários e científicos à parte, sem dúvidas, a extradição envolve ambas as áreas, sendo, naturalmente, um instituto de Direito Internacional. O seu objetivo é justamente permitir o combate pelos países contra a criminalidade, de modo a punir os criminosos e a erradicar esses chamados paraísos ou valhacoutos em que estes se escondem da Justiça; sem, entretanto, olvidar direitos, deveres, e, mesmo, garantias outorgadas aos estrangeiros, quando da aplicação do instituto.

No âmbito do Direito Internacional Privado, a Condição Jurídica do Estrangeiro abarca os direitos e deveres dos estrangeiros e divide-se em três aspectos: a) direito de entrada, b) direito de estada, e c) direito de saída do estrangeiro.

O direito de entrada constituiu-se a partir do chamado princípio da admissão discricionária do estrangeiro. Tal princípio permite que a admissão dos estrangeiros em território nacional possa ser sempre discricionária, já que se trata de um ato soberano. A priori, no Brasil vigora a livre circulação do estrangeiro, ou seja, todo aquele que satisfizer as condições de entrada no país poderá nele entrar e permanecer. O estrangeiro deverá, portanto, possuir um dos variados tipos de vistos, ou então, nos casos em que houver reciprocidade com o seu país de origem, não precisará de vistos, mas terá uma estadia limitada.

Há ainda duas formas especiais de entrada. Em primeiro lugar temos o asilo, que é uma medida política e soberana concedida pelo Presidente da República e que não admite revisão. A outra forma especial de entrada é o refúgio, concedido pelo CONARE, que analisa se o indivíduo preenche os requisitos

do DIPRI ao conflito de leis, o conflito de jurisdições também vem sendo incluído no DIPRI e hoje muitos autores se dedicam ao chamado "internationales Zivilverfahrensrecht". 
previstos na Lei $\mathrm{n}^{0} 9.464 / 97 \mathrm{e}$, contrariamente à primeira forma, admite revisão judicial. O mero pedido de refúgio suspende todo e qualquer procedimento de saída compulsória (deportação, expulsão, extradição).

Uma vez que se encontra dentro do território, incide sobre o indivíduo o direito de estada. Dividem-se os estrangeiros em: regulares, que possuirão um visto, temporário ou permanente; e irregulares, que poderão ser meramente irregulares, tais como os que entraram com um visto para turistas, mas permaneceram no país por mais tempo, ou clandestinos, que são aqueles quando o país sequer foi capaz de detectar a sua entrada em território nacional.

Os direitos e garantias fundamentais são assegurados a todos os estrangeiros. Embora se diga que estariam apenas os estrangeiros regulares abrangidos por essa proteção, na prática também estão compreendidos neste apoio os irregulares.

Por fim, o direito de saída é, em regra, livre. Mas há casos em que a saída será compulsória. São os casos de: a) deportação, quando há irregularidade na permanência ou entrada do estrangeiro no Brasil; b) expulsão, quando o estrangeiro de alguma forma desrespeita a ordem pública ou mostra-se nocivo ao interesse nacional, seja em hipóteses subjetivas analisadas pelo Estado, ou, em hipóteses previamente estabelecidas na lei, como a entrada ou permanência no Brasil, mediante fraude; e, c) extradição, quando um Estado estrangeiro solicita ao Brasil a entrega de criminoso ou suposto criminoso que aqui se encontra, para que, respectivamente, cumpra pena, ou, seja julgado no Estado requerente.

\section{O INSTITUTO DA EXTRADIÇÃO NO BRASIL}

A extradição é um mecanismo de cooperação internacional em matéria penal, cujo objetivo é o combate à criminalidade, por meio do qual um Estado requerente solicita a um Estado requerido a extradição de um criminoso ou suposto criminoso.

Conceitua-a Celso Duvivier de Albuquerque Mello5 como "o ato por meio do qual um indivíduo é entregue por um Estado a outro, que seja competente a

\footnotetext{
5 MELLO, Celso D. de Albuquerque. Curso de Direito Internacional Público. Volume 2. $13^{\text {a }}$ ed. Rio de Janeiro: Renovar, 2001. p.957.

Revista de Direito Internacional do Programa de Pós-Graduação em Direito da UERJ 
fim de processá-lo e puni-lo”. Por sua vez, Jacob Dolinger ${ }^{6}$ entende a extradição como

o processo pelo qual um Estado atende ao pedido de outro Estado, remetendo-lhe pessoa processada no país solicitante por crime punido na legislação de ambos os países, não se extraditando, via de regra, nacional do país solicitado.

A entrega do extraditando ao país requerente se perfaz, conforme 0 art. 76 da Lei $\mathrm{n}^{0} 6.815 / 80$, tanto por força de um vinculo jurídico constituído por: a) tratado internacional, podendo ser bilateral (entre dois Estados como o Tratado entre Brasil e Portugal promulgado pelo Decreto $\mathrm{n}^{0}$ 1.135/94) ou multilateral (como o Tratado de Extradição entre os Estados Parte do Mercosul, promulgado pelo Decreto $\mathrm{n}^{0}$ 4.975/04); ou por, b) promessa de reciprocidade em tratamento de casos análogos (como é o caso da Alemanha - Ext. 751 ou da Suécia - Ext. 1156), devendo ser observadas, ainda, as normas previstas na Lei $n^{0} 6.815 / 80$.

Nos artigos 76 a 94 do Título IX da Lei n ${ }^{0} 6.815 / 80$, também denominada de Estatuto do Estrangeiro, estão positivadas as normas e princípios que disciplinarão a Extradição, fora àquelas firmadas em tratados internacionais.

O processo de extradição no Brasil é misto, ou seja, é composto por uma fase administrativa, e, outra judicial. De início, envolve a esfera administrativa, já que o pedido é feito por via diplomática ao Ministério das Relações Exteriores (art. 80 do Estatuto do Estrangeiro). Este remete o pedido ao Ministério da Justiça que, após uma prévia análise de admissibilidade conforme o Tratado (se houver) e segundo as normas do Estatuto do Estrangeiro, encaminha o pedido através de Aviso Ministerial ao Supremo Tribunal Federal. Compete à Egrégia Corte proceder ao exame de legalidade do pleito, deferindo a extradição ou não. Por fim, o Presidente da República, como Chefe do Poder Executivo, determinará pela entrega ou não do Extraditando, não sendo obrigado a se vincular à decisão do Supremo. É a instância executiva quem tem, portanto, a atuação decisiva: a palavra final.

A análise legal do pleito pelo Supremo, positivada pelo art. 102, I, g da Constituição da República Federativa do Brasil, é de suma importância. Clara é a redação do art. 83 do Estatuto do Estrangeiro, quando estabelece que nenhuma extradição será concedida sem prévio pronunciamento da Corte Suprema sobre a

\footnotetext{
${ }^{6}$ DOLINGER, Jacob. Direito Internacional Privado: Parte Geral. 10 ed. Rio de Janeiro: GEN Forense, 2011. p.126.

$172 \quad$ Cosmopolitan Law Journal, v. 2, n. 1, jun. 2014, p. 168-198
} 
legalidade e procedência do pleito. É de tal maneira imprescindível que, mesmo se o extraditando concordar com a sua extradição, ainda assim haverá o exame pelo Supremo Tribunal Federal. Sobre essa máxima, discorre o Ministro Carlos Britto na ementa da Ext. 1.016:

EXTRADIÇÃO. CONCORDÂNCIA DO EXTRADITANDO. DISPENSA DE INTERROGATÓRIO. IMPRESCINDIBILIDADE DO CONTROLE DE LEGALIDADE PELO SUPREMO TRIBUNAL FEDERAL.

A concordância do extraditando com o deferimento do pedido não afasta o controle da legalidade, efetuado pelo Supremo Tribunal Federal. Precedentes.

A avaliação feita pela Egrégia Corte Suprema do processo extradicional se restringe à observação de sua legalidade, sem tocar no mérito. Isso porque, seguindo o modelo belga, o Brasil optou pelo modelo da contenciosidade limitada. De acordo com este modelo, o julgador abstém-se, portanto, de analisar o mérito da questão evitando ofender a soberania do país competente para a execução penal. Não raro em suas defesas, os extraditandos alegam o que consideram falhas no processo criminal que sofrem nos países requerentes, sendo afastadas tais alegações por força da vedação ao Supremo de adentrar no mérito.

Por exemplo, evidencia o Ministro Celso de Mello essa limitação na ementa da Ext. 1.082, em que a República Oriental do Uruguai requeria a extradição de nacional uruguaio pela prática do crime de tráfico ilícito de entorpecentes e drogas:

\begin{abstract}
PROCESSO EXTRADICIONAL E SISTEMA DE CONTENCIOSIDADE LIMITADA: INADMISSIBILIDADE DE DISCUSSÃO SOBRE A PROVA PENAL PRODUZIDA PERANTE O ESTADO REQUERENTE.

- A ação de extradição passiva não confere, ordinariamente, ao Supremo Tribunal Federal, qualquer poder de indagação sobre o mérito da pretensão deduzida pelo Estado requerente ou sobre o contexto probatório em que a postulação extradicional se apóia, não cabendo, ainda, a esta Corte Suprema, o exame da negativa de autoria invocada pelo extraditando em sua defesa. Precedentes. Doutrina.

- O sistema de contenciosidade limitada, que caracteriza o regime jurídico da extradição passiva no direito positivo brasileiro, não permite qualquer indagação probatória pertinente ao ilícito criminal cuja persecução, no exterior, justificou o ajuizamento da demanda extradicional perante o Supremo Tribunal Federal.
\end{abstract}

A extradição só pode ser requerida uma vez, conforme determinação do art. 88 do Estatuto do Estrangeiro, mas em casos em que houver insuficiência nos documentos de instrução ao processo o Supremo pode indeferir o pedido, mas Revista de Direito Internacional do Programa de Pós-Graduação em Direito da UERJ 173 
sem o prejuízo de ser ofertado um novo pedido, anexado com os devidos documentos. Exemplo desta conduta da Corte é o caso envolvendo o extraditando Horst Michael Meffert, de nacionalidade alemã, acusado de cometer furto qualificado e estelionato. Neste caso, a extradição foi primeiramente requerida pelo Governo da Alemanha na Ext. 988, que foi indeferida por não cumprimento de diligência de instrução de documentos essenciais à análise do pleito, mas o estrangeiro veio a ser extraditado através do novo pedido formulado pela Alemanha na Ext. 1.078.

A possibilidade de conversão do processo de extradição em diligência está positivada no art. 85, §2 do Estatuto do Estrangeiro. O Estado requerente terá o prazo de 60 (sessenta) dias, a contar da data de notificação do Ministério de Relações Exteriores à missão diplomática (art. 85, §3, Estatuto do Estrangeiro), para suprir as carências de documentos ou informações no processo. Passado o lapso temporal, será julgado o pedido, independentemente de resposta ou não pelo Estado requerente.

Faz parte do procedimento da extradição a prisão preventiva do extraditando, que é um requisito essencial para o prosseguimento da extradição. O pedido de extradição só terá prosseguimento após a prisão preventiva do extraditando: é o que estipula o art. 84 da Lei no $6.815 / 80$. É uma medida cautelar para garantir a entrega do extraditando, caso seja deferida a extradição.

Essa prisão preventiva é distinta daquela prevista nos arts. 311 a 316 do Código de Processo Penal. Não fere o princípio da presunção de inocência, já que a prisão se perfaz por mera necessidade instrumental, dado que, sem esta, não correrá o processo extradicional, conforme estipula o art. 208 do Regimento Interno do Supremo Tribunal Federal.

Embora o art. 81 do Estatuto do Estrangeiro contenha a previsão de que o Ministério da Justiça atua como responsável pela emissão da ordem de prisão preventiva, é pacífico o entendimento pela doutrina e pela jurisprudência, de que esta será concedida por um dos ministros do Supremo e deverá seguir os ditames do subsequente art. 82.

A derrogação do art. 81, que modificou a competência de decretação de prisão preventiva do Ministro da Justiça para o Ministro Relator do processo que tramita no Supremo Tribunal Federal, deu-se em virtude da Constituição de 1988. A previsão do art. $5^{\circ}$, LXI da Carta Magna passou a atribuir à autoridade 
judiciária a exclusividade no poder de expedir ordem escrita e fundamentada de prisão.

Para que seja decretada a prisão pelo Ministro Relator, é preciso de autorização de prisão emitida por juiz, tribunal ou autoridade competente do Estado requerente com a devida fundamentação para a realização de tal restrição de liberdade, segundo a norma do art. 78, II do Estatuto do Estrangeiro.

A Egrégia Corte já reconheceu diversos instrumentos como institutos semelhantes ao nosso mandado de prisão em que se contém uma ordem emanada por autoridade considerada competente a decretar a prisão do indivíduo, por exemplo, o mandat d'arrêt do direito francês, o mandato di cattura no direito italiano e a identidade entre a pronúncia e o indicetment no direito norteamericano.

O recurso cabível à prisão preventiva é o habeas corpus, sendo, não obstante, rara a sua concessão pelo Supremo na prática. Aplica-se apenas aos casos excepcionalíssimos, como extraditandos com um estado grave de saúde, a prisão do extraditando em prazo maior que o permitido em lei dentre outros motivos.

$\mathrm{O}$ art. $85, \S 1^{\mathrm{o}}$ do Estatuto do Estrangeiro estabelece que a defesa do extraditando no processo de extradição está limitada às seguintes questões: a) a identidade da pessoa reclamada; b) defeito de forma dos documentos apresentados; ou a c) ilegalidade da extradição. Embora muitos dos advogados aleguem que tal restrição feriria o princípio da ampla defesa e, ipso facto, seria inconstitucional; o Supremo já declarou não ser o caso, como explicita o Ministro Celso de Mello na ementa da Ext. 1.171 da Argentina:

VALIDADE CONSTITUCIONAL DO ART. 85, § 1 DA LEI No 6.815/80. As restrições de ordem temática, estabelecidas no Estatuto do Estrangeiro (art. 85, § 1) - cuja incidência delimita, nas ações de extradição passiva, o âmbito material do exercício do direito de plenitude de defesa -, não são inconstitucionais, nem ofendem a garantia da plenitude de defesa, em face da natureza mesma de que se reveste o processo extradicional no direito brasileiro e, ainda, em decorrência do próprio modelo de contenciosidade limitada adotado pelo ordenamento positivo nacional. Precedentes.

Ainda na esfera dos princípios, a extradição, assim como os variados institutos do nosso ordenamento jurídico, rege-se por princípios que norteiam a sua aplicação pelos seus operadores, buscando conferir a maior proteção possível ao extraditando. Dois princípios são considerados unanimemente pela doutrina 
como os vetores do processo extradicional, são eles, segundo Cahali7 são eles: o princípio da especialidade, também conhecido como efeito limitativo da extradição, posto que veda o julgamento do extraditando por delito diferente do que fundamentou o pedido de extradição, sendo positivado pelo art. 91, I do Estatuto do Estrangeiro; e, o princípio da identidade $e_{2}$ ou da dupla incriminação do fato, que determina que a extradição só poderá ser concedida pelo Estado requerido quando o delito imputado ao extraditando seja considerado crime nos dois países, ou seja, seja uma ação típica, antijurídica e culpável, e sua positivação é dada pelo art. 77, II do E.E..

Celso D. de Albuquerque Mello ${ }^{8}$, por sua vez, aponta um terceiro princípio, que considera quase universal - o princípio da não extradição de nacional ${ }_{2}$ cuja razão principal, explica, é que o Estado tem a obrigação de proteger os seus nacionais, ao que se rebate que, mesmo que seja o indivíduo julgado em seu país, devido as dificuldades, como a distância do local da prática do delito ou ainda a dificuldade de provas, acaba ficando impune, o que certamente constitui uma postura contrária à cooperação internacional para a repressão do crime.

Camila Carneiro9, seguindo a doutrina de Kleber Velloso, faz menção em sua obra a mais um princípio, qual seja, o princípio do non bis in idem. Tal princípio determina que, uma vez que o pedido de extradição tenha sido negado, não poderá o Estado requerente fazer novo pedido baseado no mesmo fato, a não ser que prove a existência de erro formal ou material que tenha viciado o pedido, conforme dita $o$ art. 88 da Lei $n^{0} 6.815 / 80$.

Para fins acadêmicos, ou seja, de modo a nos facilitar a compreender o instituto, classifica-se a extradição em seus diversos aspectos. Primeiramente, diferencia-se da seguinte forma, quanto à formalidade do procedimento: a) extradição de fato, que é a entrega sumária de um indivíduo sem a observância das normas legais, o que ocorre, geralmente, em cidades fronteiriças como a cidade de Uruguaiana no Sul do país, que faz fronteira com o Uruguai. Não é, no entanto, a mesma coisa que a abdução internacional ${ }^{10}$, em que um Estado

7 CAHALI, Yussef Said. Estatuto do Estrangeiro. $2^{\text {a }}$ Ed. São Paulo: Editora Revista dos Tribunais, 2010. P.259.

${ }^{8}$ MELLO, Celso D. de Albuquerque. Op. cit. P. 961-963.

9 CARNEIRO, Camila Tagliani. A Extradição no Ordenamento Jurídico Brasileiro. São Paulo: Memória Jurídica Editora. 2002. p.49.

${ }^{10}$ Um exemplo famoso de abdução internacional foi o caso de Adolf Eichmann, na Argentina, que foi capturado pelo Estado Israelense em 1960 em Buenos Aires, sem qualquer notificação às 176

Cosmopolitan Law Journal, v. 2, n. 1, jun. 2014, p. 168-198 
apreende um suposto criminoso em território alheio. Na extradição de fato, é o Estado que entrega ao outro, mas sem a observância das normas legais; b) extradição de direito, que é a entrega do indivíduo reclamado ao outro Estado, respeitando as formalidades legais, sejam internacionais ou internas. É a extradição que foi selecionada para ser objeto de estudo da presente pesquisa.

A extradição é uma relação entre dois Estados, configurando assim um pólo ativo, que recebe, e um pólo passivo, que concede. A partir daí, surge uma outra classificação, considerando a atuação do Estado envolvido, na relação extradicional: a) ativa, quando o Estado requer ao outro a entrega de um indivíduo para que este responda a processo ou cumpra pena. Neste caso, evidencia-se o caráter administrativo e político, já que procura-se efetivar a execução penal do país; e, b) passiva, quando o Estado recebe o pedido de extradição dirigido por outro Estado, que se considera competente para julgar ou forçar o cumprimento da pena. Nesta ótica, prepondera o caráter jurisdicional, já que serão juridicamente analisadas as condições desse pedido e sua procedência.

Quanto à fase processual em que se encontra a punição do Estado contra o delito objeto do pedido de extradição, a extradição poderá ser a) instrutória, quando o processo contra o Extraditando no país requerido encontra-se ainda na fase processual, sendo a prisão do extraditando autorizada por juiz, tribunal ou autoridade competente do Estado requerente, e, o objetivo é submeter o extraditando a persecução criminal, no Estado requerente; ou, b) executória, quando já houver uma sentença condenatória decorrente de processo criminal contra o extraditando, em que se imputa a este uma pena a ser cumprida, sendo a efetivação do cumprimento da pena o foco do pedido.

Menos exploradas estão as classificações como a diferenciação entre a extradição requerida, em que o Estado requer ao outro a entrega, sendo a forma habitual em que se opera a extradição entre os países; e, a extradição espontânea, na qual o Estado em que se encontra o indivíduo entrega-o, independentemente de pedido anterior. A extradição espontânea, portanto, devido à sua particularidade, não é propriamente uma extradição, assim como a extradição de fato, já que lhe carecem elementos básicos da extradição. Outra classificação

autoridades argentinas. Posteriormente, foi condenado à pena máxima, pelos crimes cometidos sob o nazismo, sem qualquer menção à forma abusiva a que foi capturado.

Revista de Direito Internacional do Programa de Pós-Graduação em Direito da UERJ 
pouco utilizada é a da extradição voluntária, quando o indivíduo voluntariamente se entrega ao Estado requerente, e a extradição involuntária, em que o Estado força a extradição do extraditando. Existe ainda a denominada "extradição de trânsito" quando o extraditando, para chegar ao Estado que requereu a sua extradição, tem que passar por um terceiro Estado onde haveria a extradição de trânsito. No entanto, ela não tem fundamento legal visto que o terceiro não concede uma nova extradição, apenas permite a passagem do extraditando por seu território.

Em alguns raros casos, surge o caso de reextradição, que ocorre, quando um indivíduo extraditado para um Estado sofre um novo pedido de extradição, agora para um terceiro Estado. Nesse caso, só poderá ser concedida com a anuência do primeiro Estado, ou seja, daquele em que o indivíduo se encontrava antes de ser extraditado. Um exemplo de como se opera o instituto foi o que ocorreu na Questão de Ordem da Extradição 851 requerida pela Alemanha, em que se pedia a permissão para a extradição do indivíduo a um terceiro país, no caso, a Áustria. Operou-se o trâmite legal de avaliação, sendo inclusive enviada Carta Rogatória para interrogatório do indivíduo situado na Alemanha, mas ao retorno desta, desistiu o país de dar prosseguimento ao pedido de reextradição.

Em relação à possibilidade de o indivíduo ser extraditado, a princípio, qualquer um que tenha cometido um delito é passível de extradição. Não obstante, pela legislação brasileira, há algumas exceções a esta regra: a nacionalidade e a condição pessoal do indivíduo.

Conforme já ressaltado, vigora no Brasil, em respeito ao nacional, o princípio da inextraditabilidade. Um brasileiro nato jamais será extraditado. A exceção será o brasileiro naturalizado que tenha cometido crime antes da naturalização, ou, quando tiver comprovado envolvimento com o tráfico ilícito de entorpecentes. O art. 77, I do Estatuto do Estrangeiro já previa a primeira hipótese; reforçada pela Constituição Federal do Brasil de 1988, em seu art. $5^{\circ}$, LI, que ainda ampliou o âmbito de sua aplicação para a segunda hipótese também. Conforme já dito anteriormente, a justificativa para essa exceção é a obrigação de o Estado zelar pelos cidadãos, de forma que se evite a provável imparcialidade da justiça estrangeira e a dificuldade de defesa pelo extraditado. No âmbito do Direito Internacional, tal postura é criticada, posto que obstaculiza a cooperação internacional almejada, bem como a extinção da distinção entre 178 
nacionais e estrangeiros. Os países do "Common Law", como o Reino Unido e os Estados Unidos da América não seguem o princípio da não-extradição do nacional.

Outro efeito do princípio supramencionado é o de obstar a extradição do nacional brasileiro nato que possua outra nacionalidade, ou seja, quando ocorre o fenômeno da dupla nacionalidade. Acerca desta proibição, em estudo analítico de um caso concreto, Carmen Tiburcio assevera que como uma das nacionalidades é a brasileira e a questão é discutida no território pátrio, será esta que interessará ao julgador brasileiro, posto que "a nacionalidade estrangeira não tem qualquer relevância no plano interno"11.

Por sua vez, a condição pessoal do indivíduo representa o caso dos Chefes de Estado ou soberanos estrangeiros, que, durante o exercício de suas funções, não poderão ser extraditados. Da mesma proteção, usufruem os agentes diplomáticos, os refugiados, os extraditandos que fogem para país no qual não seja prevista a pena capital que lhe foi imputada, ou aquele que se encontra no território do Estado requerido por motivo de força maior.

Assim como há pessoas que não podem ser extraditadas em virtude de uma condição especial que detém, existem crimes pelos quais o indivíduo não poderá ser extraditado. $A b$ initio, quanto aos delitos não passíveis de extradição, destacam-se as vedações constantes no art. 77 da Lei $\mathrm{n}^{0}$ 6.815, dispositivo este que é fundamental no processo extradicional, por determinar quando a extradição não será concedida por possuir uma das particularidades listadas em seus incisos. Entre outras condições, destacamos: a) o fato de o crime não constituir crime no Brasil ou no país requerente; b) a hipótese de a lei brasileira impor ao crime pena de prisão inferior ou igual a 1 ano; ou, c) o fato imputado constituir crime político.

Assim, para se avaliar se o fato imputado ao extraditando constitui crime nos dois países, conforme estabelece o inciso II do art. 77, o Supremo Tribunal Federal tem decidido a partir de análise dos elementos do tipo relativo ao fato, não se baseando exclusivamente no nomen juris, que não precisa ser idêntico. Entende-se que, se no tipo penal brasileiro se encontram os mesmos elementos

${ }^{11}$ TIBURCIO, Carmen. Temas de Direito Internacional. Rio de Janeiro: Renovar, 2006. P.275.

Revista de Direito Internacional do Programa de Pós-Graduação em Direito da UERJ 179 
presentes na tipificação no Estado requerente, será suficiente para configurar-se a dupla tipicidade necessária à concessão da extradição.

Os incisos III e V do art. 77 do Estatuto do Estrangeiro envolvem a competência do Estado brasileiro para julgar o crime em questão. De início, pode parecer confuso que, no inciso III, diga-se que, quando houver competência do Brasil, será negada, e, no inciso V, somente seria negada, se o Brasil já estiver processando, ou, já tiver condenado ou absolvido o extraditando pelo mesmo fato. Elucidamos a questão a partir do seguinte raciocínio lógico: no inciso III, o dispositivo recai sobre aqueles crimes cuja competência é PRIVATIVA do Brasil para julgar o crime; ao passo que, os casos do inciso V são aqueles em que ocorre a competência concorrente entre o Brasil e o Estado requerente; como acontece, não raro, nos casos de tráfico ilícito de entorpecentes.

Quanto à exigência do inciso IV do art. 77 do Estatuto do Estrangeiro, que veda a extradição se a pena for igual ou inferior a 1 ano; é pacífico o entendimento de que, em razão de benefício ao réu, deve-se considerar a pena mínima in abstracto, para decidir se o crime é ou não passível de extradição. A imposição de um quantum mínimo de pena para a concessão da extradição revela que o Brasil opta por não prestigiar a extradição, quando o crime for considerado de menor potencial lesivo, em razão da imposição de pena mais reduzida. Quanto ao grau de lesividade da conduta, é importante esclarecer que a extradição somente poderia ser requerida para crimes, jamais para contravenções; já que a doutrina e a jurisprudência apontam para uma aplicação literal do texto do Estatuto do Estrangeiro, que somente se refere a crime, ao falar da extradição; jamais se referindo a contravenção.

A prescrição, causa impeditiva da extradição, constante no inciso VI do já citado art. 77 do Estatuto do Estrangeiro, é uma circunstância que muito incide como motivo de indeferimento das extradições. Imprescindível é a aferição da prescrição tanto pela legislação brasileira, quanto pela legislação estrangeira, sendo, no entanto, impossível a criação de uma terceira teoria de prescrição a partir da junção das duas legislações.

Por fim, o inciso VII do supramencionado art. 77 do Estatuto do Estrangeiro, junto com o art. $5^{\circ}$, LII da Lex Maxima, vedam a extradição por crime político. São diversos os argumentos para a não-extradição por crime político, entre eles a liberdade de pensamento e a provável parcialidade do Estado 180 
em julgar aquele que cometeu crime político em sua esfera ao ser opor criminosamente.

O crime político é um crime contra o Estado requerente, não havendo que se falar em cooperação internacional ou combate pela criminalidade, tendo em vista que, para o Estado requerido, não há atentado contra a sua soberania. Situação muito diferente do que ocorre com os crimes comuns, que afrontam a todos os países.

Em alguns casos, o crime político se mescla a crimes comuns. Caberá, então, ao Supremo, conforme o $§ 2^{\mathbf{o}}$ do art. 77 da Lei $n^{0} 6.815 / 80$, avaliar qual crime prevalece, quando houver esta conexão. Isso porque, se o crime comum constituir o fato principal, proceder-se-á a extradição (art. $77, \S_{1} \mathbf{o}$ ).

O $\S 3^{\mathbf{o}}$ do art. 77 deixa claro que não serão considerados crimes políticos aqueles tentados contra chefes de Estado, ou quaisquer autoridades, ou, os atos de anarquismo, terrorismo, sabotagem, sequestro de pessoa, propaganda de guerra ou processos violentos para subverter a ordem política ou social. Isso porque não atentam contra o Estado apenas, mas contra toda a sociedade. Estas condutas são, portanto, enquadradas como crimes anti-sociais.

O inciso VIII do art. 77 do Estatuto do Estrangeiro veda a extradição, quando o extraditando for passível de ser julgado por tribunal ou juízo de exceção. A norma objetiva proteger o extraditando, com relação a um julgamento justo e imparcial, com respeito a garantias processuais e legais. Isto poderia evitar o que ocorreu, por exemplo, nos Tribunais Internacionais Penais ad hoc, instalados em Tóquio e Nuremberg, após a II Guerra Mundial, para julgar os supostos criminosos de guerra; quando muito se questionou o respeito a normas e princípios penais basilares, como a anterioridade da lei.

Os crimes militares propriamente ditos tampouco podem ser motivo de extradição. São todos aqueles crimes disciplinados por lei especial, como o Código Penal Militar Brasileiro. Justamente devido à particularidade desses crimes, não se justifica a extradição. De fato, não atinge a soberania do Estado requerido o ato que vá contra a manutenção da ordem e da disciplina nas forças armadas do Estado requerente.

Ainda os crimes contra a imprensa, por estarem dentro da esfera dos crimes de opinião, não são passíveis de extradição. Os crimes contra a religião também se encontram neste rol de crimes, e, sua inserção baseia-se na liberdade Revista de Direito Internacional do Programa de Pós-Graduação em Direito da UERJ 181 
de crença e culto. Incluem-se, por último, os crimes eleitorais, que, por só poderem ser praticados no âmbito do território do Estado requerente e somente atingindo a este, não têm repercussão internacional.

A existência de vínculo familiar entre o extraditando e brasileiros, seja por ter companheira, esposa ou filhos brasileiros, não é empecilho a concessão da extradição, diferente do que ocorre na expulsão que, por força do art. 75, II, a e b da Lei no $6.815 / 80$, veda a expulsão nesses casos.

O argumento para a não expulsão nas exceções previstas no referido art. 75 justifica-se $^{12}$, uma vez que, em se tratando de medida administrativa que impossibilita o retorno do expulso ao país, prejudicar-se-ia assim, irremediavelmente, o convívio familiar. O mesmo não ocorre com a extradição, porque o extraditando não está proibido de retornar ao território brasileiro, apenas terá de responder a processo ou pena cominada em outro país.

O Supremo Tribunal Federal pacificou esse entendimento através do Enunciado 421 de sua Súmula: "não impede a extradição a circunstância de ser o extraditando casado com brasileira ou ter filho brasileiro".

Não constitui impedimento à concessão da extradição o fato de o extraditando responder a processo ou ter sido condenado no Brasil por crime diverso daquele ensejador do pedido de extradição. É o que preveem os artigos 89 e 90 do Estatuto do Estrangeiro.

Ficará a critério do Presidente da República o momento em que o extraditando será entregue e se esta efetivamente ocorrerá.

Após o exame procedente do Supremo Tribunal Federal e a concordância pelo Presidente da República, a entrega do extraditando seguirá o rito previsto no art. 86 da Lei $n^{0} 6.815 / 80$. Terá o Estado requerente o prazo de 60 (sessenta) dias para retirar o extraditando após a comunicação pelo Ministério das Relações Exteriores a sua missão diplomática, sob pena de, ultrapassado este prazo, conforme observa o art. 87 do mesmo diploma legal, ser posto em liberdade o extraditando.

Para a efetivação da extradição, o Estado requerente deverá ainda se comprometer a observar os incisos do art. 91 do Estatuto do Estrangeiro, que, dentre outras questões, estipulam a promessa de não processar ou prender o

\footnotetext{
${ }^{12}$ Os tribunais brasileiros têm dado uma aplicação ampla a este dispositivo, em sede de expulsão, prestigiando a convivência familiar dos familiares brasileiros, com o possível expulsando. 182

Cosmopolitan Law Journal, v. 2, n. 1, jun. 2014, p. 168-198
} 
extraditando por fatos anteriores ao pedido (a menos que seja requerida a sua admissão através de pedido de extensão da extradição) ou ainda a obrigatoriedade de efetuar a detração, ou seja, computar o tempo de prisão que sofreu no Brasil na pena a ser cumprida no Estado requerente.

\section{A JURISPRUDÊNCIA DO SUPREMO TRIBUNAL FEDERAL SOBRE EXTRADIÇÃO}

Após o estudo da doutrina, partimos para a segunda fase da pesquisa, em que, objetiva-se traçar o atual perfil do Supremo Tribunal Federal, tendo como base as decisões proferidas, e, desta forma, demonstrar que nossa Corte Suprema aplica adequadamente o Direito Extradicional, em vigor no Brasil, e, em nada contribui para a fama de ser o país um refúgio de impunidade para criminosos estrangeiros.

Esclarecemos que utilizamos o recurso de busca de jurisprudência disponibilizado pelo sítio eletrônico do Supremo Tribunal Federal, para localizarmos o máximo possível de acórdãos relacionados à Extradição. A partir do resultado da busca, delimitamos a procura pelo lapso temporal compreendido entre 2000 a 2010, para que, a partir das decisões encontradas neste período, chegássemos a uma posição sobre a Corte Suprema.

Foram encontrados 377 acórdãos relacionados à extradição, sendo que 279 destes eram os processos extradicionais propriamente ditos e os 98 acórdãos restantes se dividiram em inúmeros incidentes processuais tais como Embargos de Declaração, Questão de Ordem, Pedidos de Extensão ou Agravos. Ainda em meios aos resultados disponibilizados pelo sítio, encontramos 68 acórdãos de Habeas Corpus relacionados, em sua grande maioria, ao relaxamento de Prisão Preventiva em processos extradicionais.

Com a leitura dos referidos acórdãos, levantamos uma série de dados para então elaborarmos os gráficos que se seguem. 


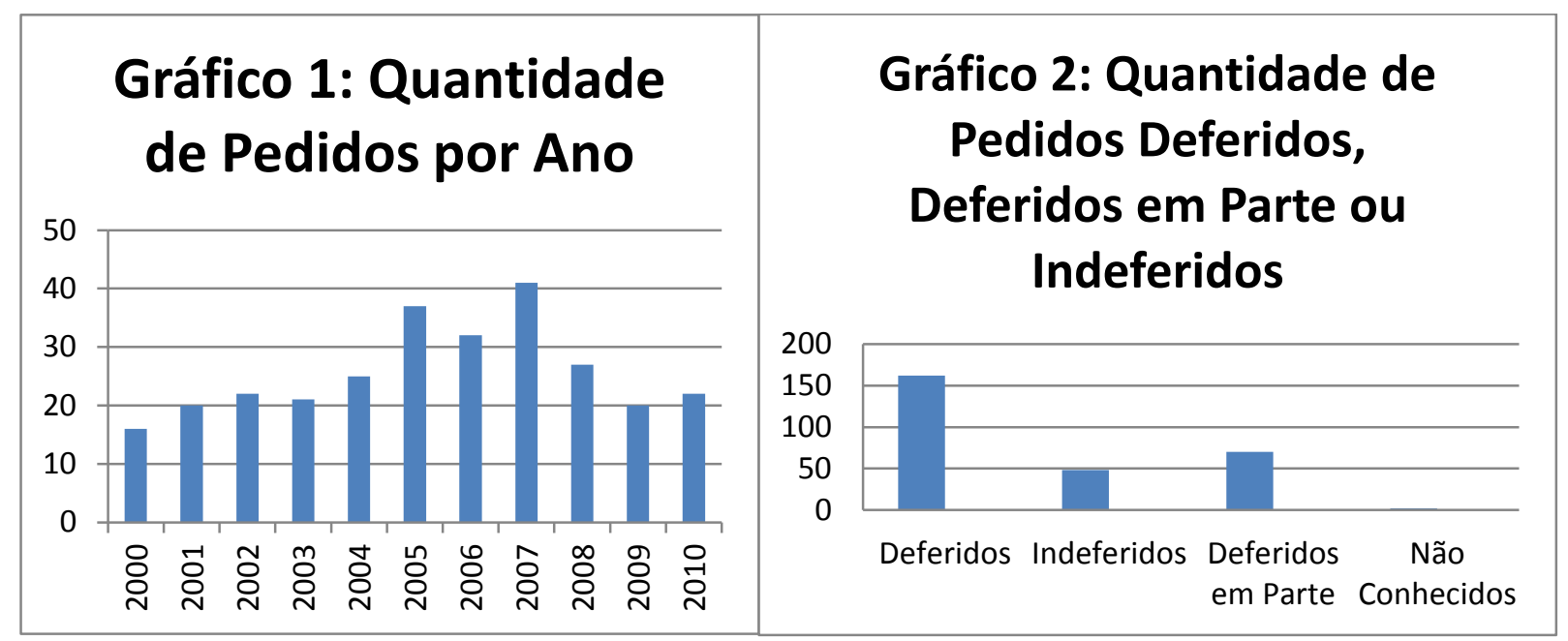

Os dois primeiros gráficos tratam, respectivamente, sobre: 1) a quantidade de pedidos de extradição em cada ano, em que podemos observar que, com exceção do intervalo em 2005 e 2007, em que houve uma maior demanda; a média geral era entre 20 e 25 pedidos extradicionais por ano; e 2) a quantidade de pedidos de extradição que foram deferidos, deferidos em parte ou indeferidos durante o período analisado. Destacam-se, ainda, dois casos de extinção sem resolução de mérito, em que se considerou como não conhecido o pedido de extradição devido à condição de refugiados dos dois extraditandos.

O segundo gráfico torna visível que, na maioria dos casos, a extradição é concedida, total ou parcialmente. A partir, portanto, desse resultado obtido através da pesquisa de uma relevante amostra de casos, a outra conclusão não se pode chegar a não ser a de que, como alegado de início, o Supremo Tribunal Federal em sua função de exame da legalidade dos processos extradicionais, tem apresentado uma postura de efetiva cooperação com os outros países, na busca pela erradicação da criminalidade em nível mundial.

Os casos em que o pleito extradicional foi indeferido corresponderam a meros $17 \%$ (51 casos) no universo dos casos selecionados pela amostragem entre o período do ano de 2000 a 2010. Entre as causas que culminaram no indeferimento do processo extradicional, estão aquelas previstas no art. 77 do Estatuto do Estrangeiro, principalmente aquela que versa sobre a impossibilidade da extradição, quando se operar a prescrição seja pela lei brasileira ou pela estrangeira.

O gráfico abaixo procura evidenciar as principais causas que ensejaram o indeferimento: 




Como dito anteriormente, a prescrição foi, entre os motivos para indeferimento, a que mais ocorreu. Mas outra causa que também apresentou um número considerável foi a insuficiência nos documentos, tais como ausência de algum documento ou ainda, por exemplo, nos casos de cálculo de prescrição executória, a não indicação de cada pena cominada individualmente a cada crime.

Tiveram a mesma incidência como causa do indeferimento: o fato de a pena a ser cumprida ser inferior a 1 ano; o extraditando responder criminalmente por mesmo fato no Brasil; e, a não ocorrência da dupla tipicidade, ou seja, não ser crime no Brasil a conduta imputada ao extraditando pelo Estado requerente.

Não menos importantes são os três casos, correspondentes a $5 \%$, em que o indeferimento deu-se por possuir o extraditando a condição de brasileiro nato ou naturalizado. Deve ser ressaltado que, como ocorreu num dos casos, apesar da previsão de extradição de naturalizado devido ao tráfico de drogas; em virtude de ausência de lei regulando especificamente o dispositivo do art. $5^{\circ}$, LI da Constituição da República Federativa do Brasil, o Supremo Tribunal Federal só tem deferido os casos em que for comprovado o envolvimento do extraditando, ou seja, nas Extradições Executórias.

Temos ainda dois casos em que a Corte Suprema considerou os crimes imputados ao extraditando como crimes políticos, hipótese essa que, conforme o art. 77, VII do Estatuto do Estrangeiro, cumulado com o art. $5^{\circ}$, LII da CRFB, enseja a impossibilidade de se extraditar o indivíduo. 
Por fim, restaram os variados motivos que se englobaram como "Outros". Estes compreendem casos como a ausência do crime no rol taxativo de crimes passíveis a extradição entre os dois países, ou a impossibilidade de se proceder a promessa de reciprocidade por incompatibilidade de leis entre os dois países, ou a incompetência do Estado requerente para julgar o fato, dentre outros motivos.

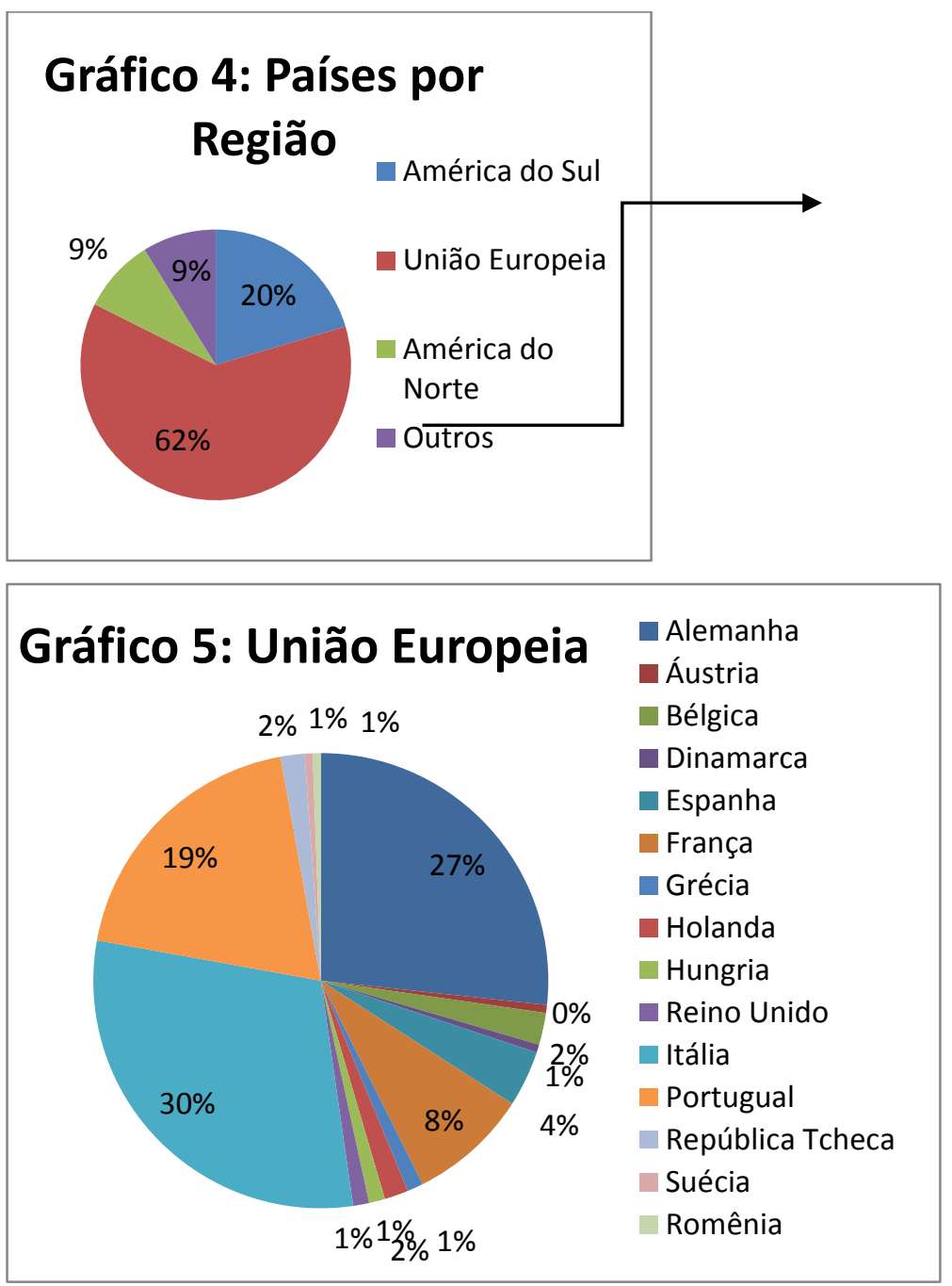

Nos gráficos acima, evidencia-se quais foram os Estados que postularam pedidos extradicionais no período analisado. O primeiro deles versa sobre a quantidade de pedidos de extradição conforme a região do planeta em que se encontra o Estado requerente. Em virtude do número elevado de demandas oriundas da União Europeia, entendeu-se como relevante a construção do segundo gráfico, com a porcentagem de pedidos por país integrante deste bloco.

Três países contribuíram para que a União Europeia se sobressaísse sobre as demais regiões no primeiro gráfico. Conforme se evidencia no segundo gráfico, 186 
a Itália foi o país que mais pedidos de extradição fez ao Brasil, seguida pela Alemanha e Portugal. Uma especulação possível é a de que, devido aos laços históricos existentes entre estes países e o Brasil, por exemplo, graças à imigração, o Brasil é um país não hostil à recepção de nacionais destes três países. Fica a advertência, contudo, que não passa esta hipótese levantada de uma mera conjectura a partir dos resultados obtidos, sem ter quaisquer dados empíricos que a comprovem.

Deve ser destacado ainda o resultado dos países da América do Sul, segunda região com mais pedidos, o que é esperado, já que o Brasil faz fronteira com quase todos os países do continente, facilitando a vinda dos extraditandos para o Brasil. Além disso, nosso país possui diversos tratados com os países vizinhos, havendo, inclusive, um tratado multilateral do Mercosul - Decreto $\mathrm{n}^{\mathrm{o}}$ 4.975/o4 - para facilitar a extradição entres os países membros do bloco.

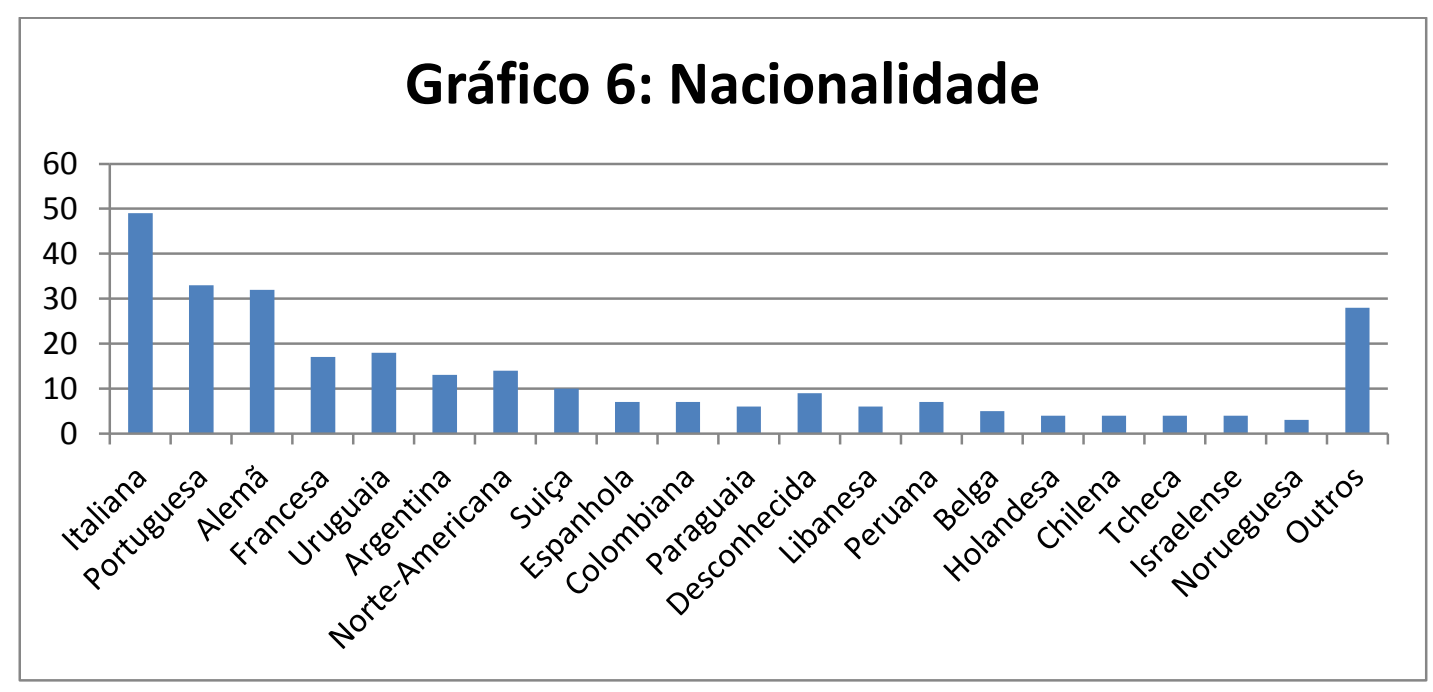

Após os primeiros resultados, nos quais levantarmos quais foram os Estados que requereram a extradição de indivíduos no período analisado, procuramos desvendar quais os nacionais que, alvo de pedidos extradicionais, foram efetivamente extraditados.

O gráfico de nacionalidade seguiu, em sua maior parte, a contabilidade de países requerentes. Sendo assim, os extraditandos de nacionalidade italiana, que foi o país que teve um maior número de pedidos extradicionais, lideram o grupo de extraditandos. 
Não obstante, Portugal ultrapassou a Alemanha, que era a segunda entre os Estados requerentes. Isso se justifica porque a Alemanha requereu a extradição não só de seus nacionais, mas também de indivíduos de várias outras nacionalidades, prática essa que Portugal não seguiu.

O número daqueles cuja nacionalidade foi considerada como "desconhecida" revelou-se maior do que o esperado. Tal fato se justifica, contudo, pois não só houve casos em que o próprio Estado requerente desconhecia a nacionalidade do extraditando, como também alguns acórdãos foram omissos em indicar a nacionalidade do indivíduo sob análise.

Os norte-americanos, assim como os alemães, também tiveram um número abaixo do esperado pelo mesmo motivo, qual seja, inúmeros de seus pedidos incidiam não na extradição de um de seus nacionais, mas sim em pedidos de extradição de estrangeiros.

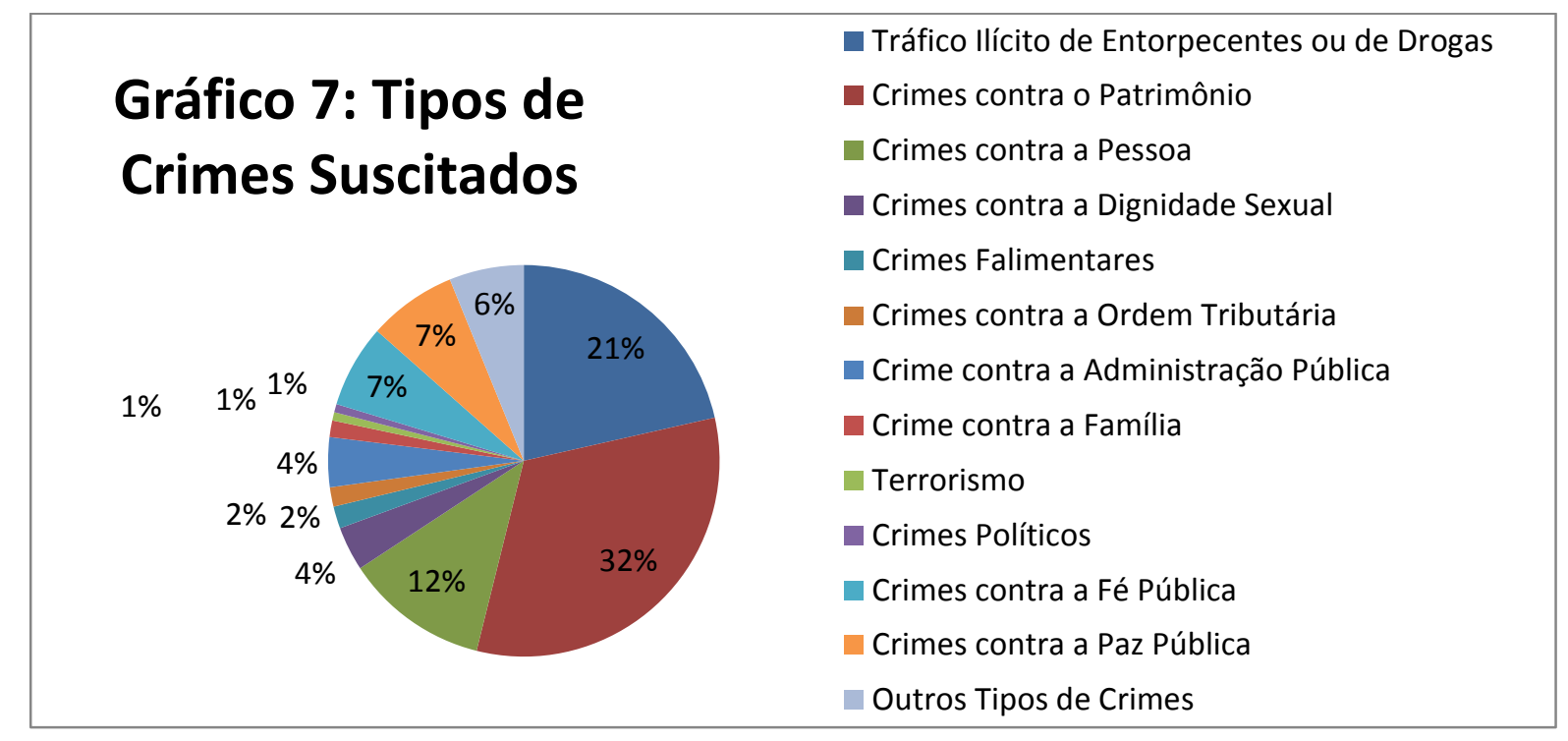

O objetivo da extradição é a cooperação internacional pelo combate ao crime, sendo assim, a aferição de quais crimes são mais suscitados nos pedidos extradicionais é de extrema relevância. Conforme os resultados demonstrados pelo gráfico, em primeiro lugar, com $32 \%$, temos os crimes contra o patrimônio, em especial o crime de estelionato, do art. 171 do Código Penal Brasileiro, que foi o crime mais práticado, segundo os pedidos extradicionais.

Observou-se, em relação ao crime de estelionato, a aplicação do que falamos anteriormente,de que para a haver a dupla tipicidade, não é preciso haver 
a semelhança no nomen juris. De fato, por exemplo, no Estados Unidos da América, na Suíça e em outros países, o crime de fraude foi equiparado ao de estelionato, ou, ainda, na Argentina e no Paraguai, o "crime de estafa" foi também considerado como equivalente ao estelionato. Já na Espanha, a denominação ao crime de estelionato foi o "crime de burla".

Destaca-se que, embora, em vários casos, o crime de falsificação de documentos - públicos ou privados - tenha sido considerado como meio de consumação de crimes como o crime de estelionato; ainda assim os crimes contra a Fé Pública tiveram uma aparição considerável (7\%).

O segundo tipo de crime com uma porcentagem considerável (21\%), foi o tráfico ilícito de entorpecentes ou de drogas. Existem provas robustas de que o Brasil está em papel de destaque na rota do tráfico internacional de drogas, portanto, seria previsível semelhante resultado. Não raro, nos casos de extradição por este crime, o indivíduo estava respondendo ou havia respondido por crime de tráfico no Brasil, por isso a defesa alegava o art. 77, V. Não obstante, graças ao entendimento da Corte Suprema de que, nos casos de tráfico internacional, há a competência concorrente dos países onde ocorreram os vários atos independentes para a prática do crime, o pedido era deferido.

O precedente de competência concorrente nos crimes de tráfico seguido pelo Supremo Tribunal Federal se baseia no art. 36, 2, a, I da Convenção Única de Nova York de 1961 que versa sobre entorpecentes e assim dispõe:

Art. 36: Disposições Penais

1. Com ressalva das limitações de natureza constitucional, cada uma das Partes se obriga a adotar as medidas necessárias a fim de que o cultivo, a produção, fabricação, extração, preparação, posse, ofertas em geral, ofertas de venda, distribuição, compra, venda, entrega a qualquer título, corretagem, despacho, despacho em trânsito, transporte, importação e exportação de entorpecentes, feitos em desacordo com a presente Convenção ou de quaisquer outros atos que, em sua opinião, contrários à mesma, sejam considerados como delituosos, se cometidos intencionalmente, e que as infrações graves sejam castigadas deforma adequada, especialmente com pena prisão ou outras de privação da liberdade.

2. Observadas as restrições estabelecidas pelas respectivas constituições, sistema legal e legislação nacional de cada Parte:

a) I - cada delito enumerado no parágrafo 1, se for cometido em diferentes países será considerado um delito distinto; (grifo nosso) 
Assim, se o Brasil foi o país em que houve a tentativa ou a efetiva exportação da droga, tal ato criminoso enseja a competência do Brasil para julgar o crime, mas não prejudica, por exemplo, a competência da Alemanha de julgar a importação da droga para o seu país.

Importante ainda ressaltar que os crimes contra a pessoa ficaram em terceiro lugar, com $12 \%$. Tal forma de delito compreendeu, em sua maioria, casos de homicídio ou tentativa deste. Os crimes contra a paz pública, assim como os contra a fé pública, alcançaram $7 \%$ dos casos. Essa proporção se explica porque o crime de quadrilha foi suscitado diversas vezes junto a outros crimes, nem sempre ocorrendo a dupla tipicidade já que, por exemplo, no Estados Unidos da América não é necessário o conluio de pelo menos três pessoas, como ocorre no Brasil. Um crime, com nomen juris distinto, que equiparou-se ao de quadrilha, foi o crime de máfia, por vezes alegado pela Itália.

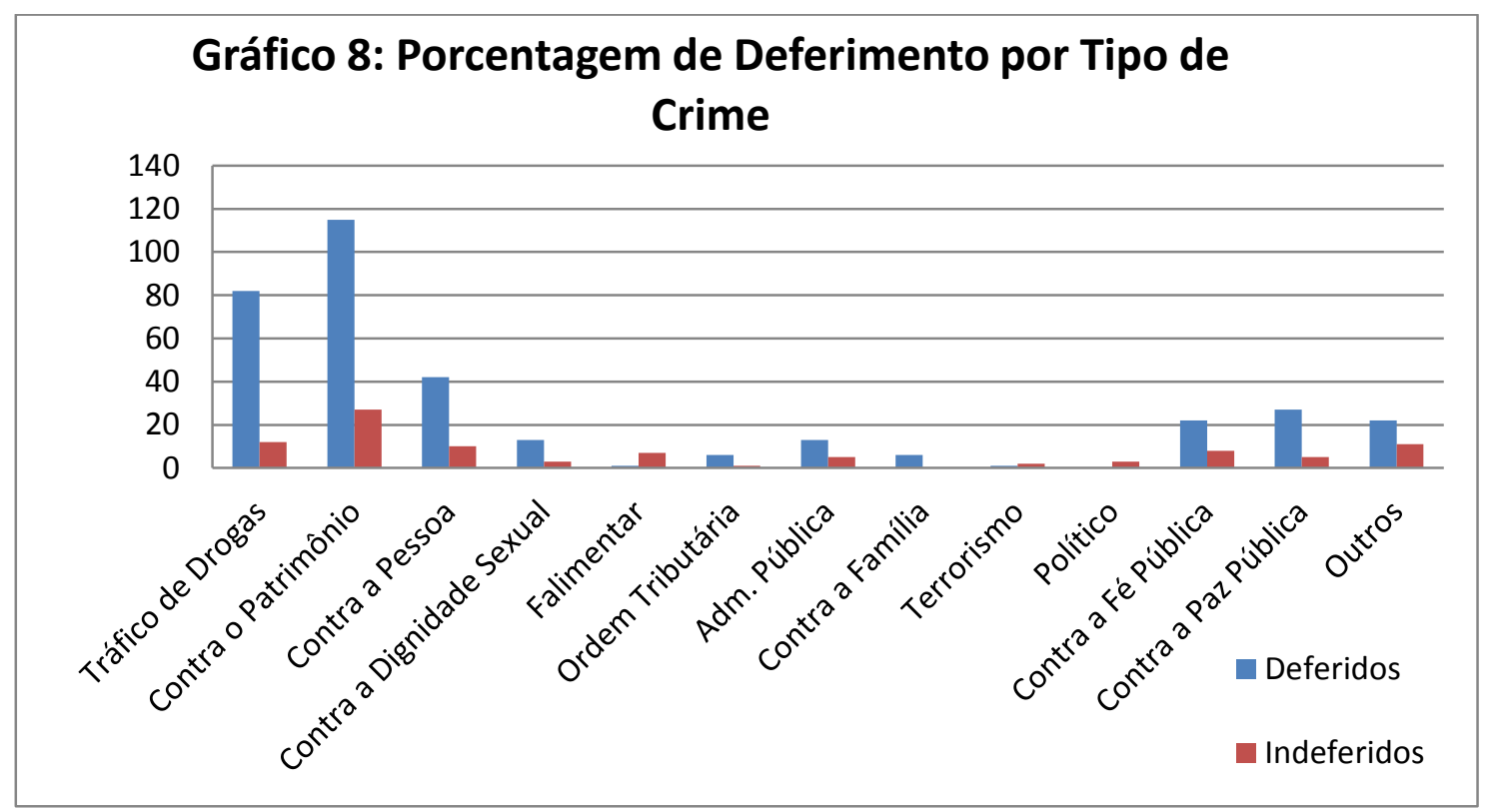

Conforme já concluímos no gráfico 2, que estabeleceu a quantidade de pedidos deferidos ou não, restou claro que os pedidos extradicionais são, em sua grande maioria, deferidos total ou parcialmente. Por tal razão, evidente que, na abordagem relativa aos diversos tipos de crime, na maior parte dos casos será preponderante a situação de deferimento do pedido. Não obstante, há casos em que os pedidos são indeferidos. Sendo assim, o gráfico acima procurou elucidar que crimes são esses, e tentaremos demonstrar porque não seriam deferidos. Inicialmente, note-se que apenas três tipos de crime apresentaram uma 
quantidade de indeferimento maior que de deferimento: os crimes falimentares; os crimes de terrorismo; e os crimes políticos.

O crime político, por ser uma hipótese em que se veda a extradição, foi, todas as vezes, indeferido, como resta claro no gráfico acima. Já os pedidos em função de crime de terrorismo não foram todos deferidos, porque dois dos três pedidos de extradição com base no crime de terrorismo, apresentaram insuficiência de documentos juntados.

Por fim, os crimes falimentares foram indeferidos em sua maior parte, já que, por diversas vezes, verificava-se a prescrição pela legislação brasileira. Acontece que os crimes falimentares possuem uma singularidade no que diz respeito a sua prescrição. Até a instauração da Lei $\mathrm{n}^{0} 11.101 / 05$, vigorava 0 Decreto $\mathrm{n}^{0} 7.661 / 45$ e o disposto na Súmula 147 do STF, que estabeleciam a prescrição a partir de dois anos contados do encerramento da falência ou do dia em que deveria encerrada. Com a nova lei, o prazo passou a fluir da data da decretação da falência, o que é benéfico para o possível extraditando. Porém, submeteu a prescrição aos prazos do Código Penal, no que foi mais rigorosa. $\mathrm{O}$ entendimento da doutrina e da jurisprudência é de que, concorrendo a essas duas regras quanto ao cálculo do lapso prescricional, prevalecerá a mais benéfica ao réu.

De fato, os pedidos extradicionais com base em crimes falimentares pelos Estados requerentes foram feitos após o lapso temporal de dois anos, conforme a Súmula 147 do STF, o que resultou num maior número de pedidos indeferidos. Levanta-se, portanto, a hipótese de que há um provável desconhecimento por parte dos outros Estados, quanto a nosso prazo singular de prescrição nos crimes falimentares.

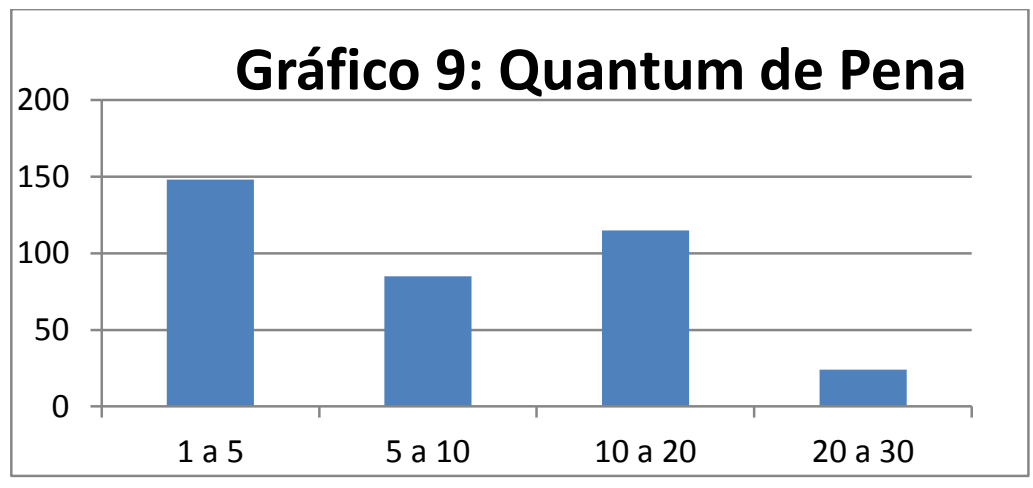


Para verificarmos o grau de periculosidade dos crimes cometidos pelos extraditandos, focamos nossa atenção nas penas cominadas para cada crime. Nos pedidos de extradição executória, consideramos a pena cominada, ou, quando havia mais de um crime, somamos as penas, já nos pedidos de extradição instrutória, usamos como parâmetro a pena-base máxima de cada crime conforme a legislação brasileira.

Os crimes de menor periculosidade, com penas superiores a 1(um) ano até 5(cinco) anos, foram a maioria. Contribuiu para tal, o crime de estelionato cuja pena-base máxima no Brasil é de 5(cinco) anos, e, o crime de quadrilha que é de 3(três) anos.

O intervalo seguinte de penas, aquelas compreendida entre penas superiores a 5(cinco) anos até $10(\mathrm{dez})$ anos, ficou em terceiro lugar. Nela estão compreendidos crimes como o de receptação, de roubo e outros crimes patrimoniais. Não obstante, o crime patrimonial que foi mais suscitado, o estelionato, compreende-se no intervalo anterior, o que auxiliou para que o primeiro intervalo ficasse em primeiro lugar.

O outro intervalo de pena que apresentou uma parte significativa foram os crimes cujas penas ficam entre 10 (dez) a 20 (vinte) anos. Justifica-se essa posição devido aos crimes de tráfico de entorpecentes, cuja pena-base máxima é de 15 (quinze) anos pela legislação brasileira.

Por último, os crimes com penas de 20 (vinte) a 30 (trinta) anos, que se reputam como crimes de grave periculosidade, tiveram uma quantidade bem inferior em comparação aos outros, constituindo-se principalmente de crimes de homicídio.

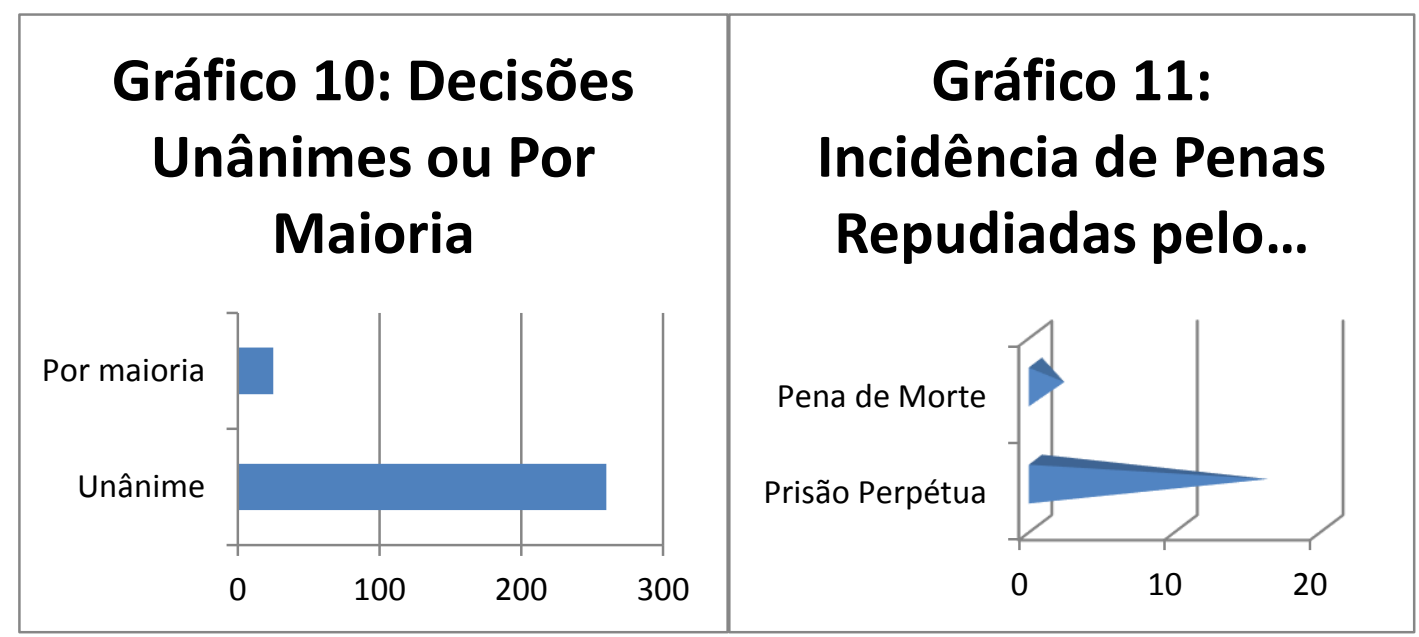


Os acórdãos analisados retratavam pedidos de extradição que, quase sempre, tinham uma decisão unânime pelos ministros do Supremo Tribunal Federal. Os raros casos em que a decisão se deu por maioria ocorreram porque, por exemplo, um ministro deferia a extradição em maior ou menor extensão que os demais ou até mesmo a indeferia. Ou então, devido à margem de discricionariedade conferida aos ministros na hora de decidir se o crime alegado no pedido foi político ou comum, em alguns acórdãos a divergência surgia porque alguns entendiam não se tratar de crime político. Outra origem de divergência foi também a discussão quanto à ocorrência de prescrição ou não no caso concreto analisado no pedido.

Um número considerável de vezes em que a decisão se deu por maioria teve como particularidade a possibilidade de o extraditando ser condenado à pena de prisão perpétua, ou quando já o havia sido.

Isso porque, embora a tradição da Corte Suprema no início do século passado fosse a de restringir a extradição em casos em que havia a prisão perpétua, a partir da Extradição $\mathrm{n}^{0} 426$ de 1985, passou a prevalecer o entendimento de que, em não havendo previsão em lei ou no tratado sobre a necessidade de ressalva quanto a pena de prisão perpétua, não haveria de ser o pedido deferido com qualquer restrição quanto a aplicação de pena de prisão perpétua.

Uma corrente seguida pelos Ministros Celso de Mello, Maurício Corrêa, Sepúlveda Pertence, Néri da Silveira e Marco Aurélio defendia o retorno da posição anterior do Supremo Tribunal Federal de vedação à prisão perpétua, mas foram inúmeras as decisões em que restaram vencidos.

$\mathrm{O}$ argumento principal destes Ministros para o retorno de tal vedação se justificava pela proibição, em nossa Constituição, à cominação e a imposição de quaisquer penas de caráter perpétuo (art. $5^{\circ}$, XLVII, b, CRFB), não podendo um tratado internacional ter precedência à nossa Magna Carta.

Foi só na Extradição $\mathrm{n}^{0}$ 855, julgada em 2004,que se modificou este entendimento, retornando ao precedente de condição à concessão do pedido extradicional ao Estado requerente, desde que este se comprometesse a não aplicar a pena de prisão perpétua, comutando-a no máximo a pena privativa de liberdade de 30 anos. 
O contexto em que se consolidou o entendimento de que a prisão perpétua é uma pena repudiada pelo Brasil, não só em âmbito interno, mas também externo, logo impossibilitando a concessão do pedido extradicional sem a comutação desta em pena privativa de liberdade de até 30 (trinta) anos, constitui um dos grandes avanços na matéria extradicional.

Sendo assim, o gráfico 11 reproduz a quantidade de vezes em que houve a incidência da prisão perpétua ou da pena de morte num pedido extradicional, seja por ter sido o extraditando condenado a uma delas, seja porque havia a possibilidade de vir a ser condenado.

Cumpre destacar que a pena de morte, bem como a pena corporal, diferente da prisão perpétua, é expressamente vedada, sendo imprescindível a sua comutação, conforme dispõe o art. 91, III, da Lei nº 6.815/80.

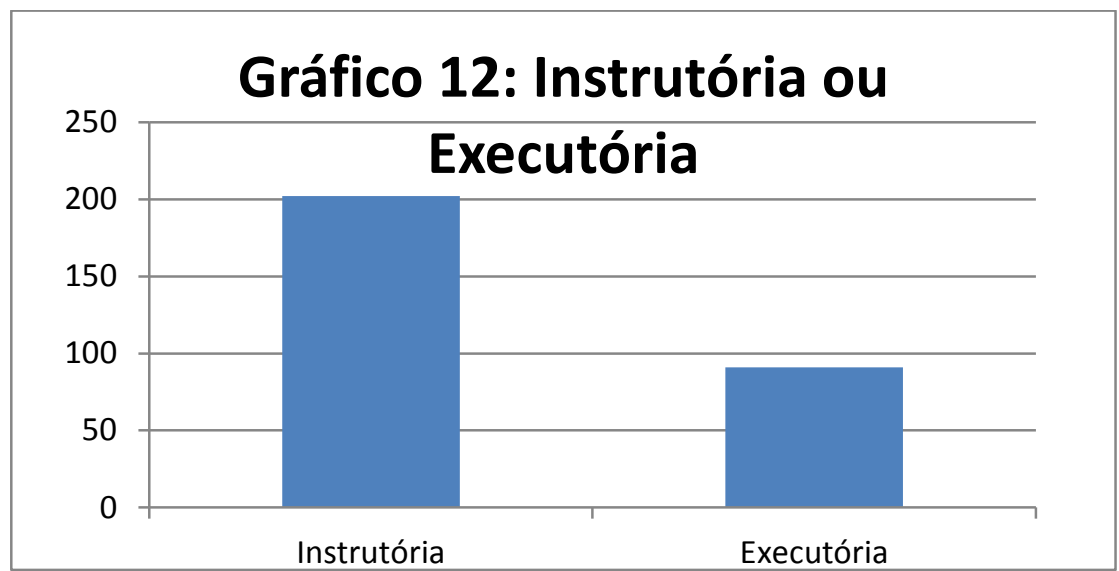

Como já dito anteriormente, a extradição poderá ser instrutória, quando o pedido se referir a um possível criminoso que ainda está sendo processado pelo Estado requerente, ou executória, quando o pedido se refere a um criminoso já condenado por um crime.

Após a leitura dos acórdãos do lapso temporal analisado, conclui-se, a partir do resultado obtido, que o número de pedidos extradicionais instrutórios é bem superior ao dos pedidos executórios. 


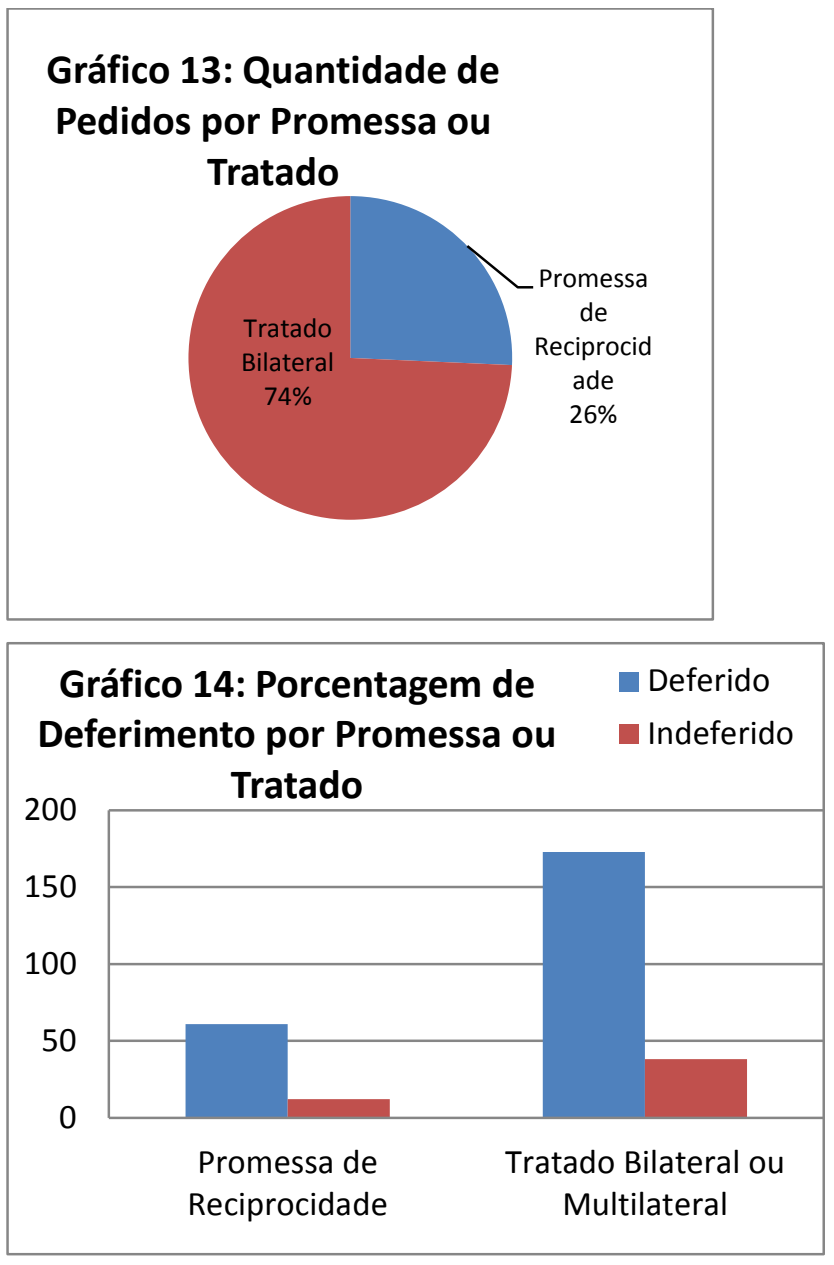

A extradição poderá ser concedida com base em tratado bilateral ou multilateral, entre o Estado requerente e o Brasil, ou através de promessa de reciprocidade, observando-se as normas constantes no Estatuto do Estrangeiro.

O gráfico 13 evidencia que o tratado entre os países é o meio em que a maioria dos pedidos extradicionais se firma, não obstante, também há uma parcela daqueles feitos baseados na promessa de reciprocidade.

Embora a existência de um tratado bilateral ou multilateral entre os dois países possa parecer uma forma mais concreta e efetiva para a concessão da extradição, a verdade é que não há diferença, ou hierarquia, entre esses dois tipos de compromissos entre os países, quando se trata de matéria extradicional.

De fato, o gráfico 14 foi elaborado com o fito de demarcar que a promessa de reciprocidade, ainda que menos utilizada, pode obter êxito, desde que observados os requisitos do Estatuto do Estrangeiro.

O maior exemplo dessa realidade é a posição da Alemanha, que opera seus pedidos extradicionais através da promessa de reciprocidade e é o segundo Revista de Direito Internacional do Programa de Pós-Graduação em Direito da UERJ 195 
Estado em maior quantidade de pedidos, tendo, inclusive, obtido o aval do Supremo para a extradição por diversas vezes.

\section{CONCLUSÃo}

O estudo da jurisprudência do Supremo Tribunal Federal sobre extradição demonstra que o número de casos em que o criminoso ou suposto criminoso é extraditado ao país requerente, idôneo a processá-lo ou comutá-lo à pena, é substancialmente superior aos casos em que a extradição é indeferida.

Partindo dos dados obtidos através de uma amostragem de acórdãos produzidos pela Corte, entre 2000 e 2010 , com a posterior análise das informações, se fez evidente a postura do Supremo Tribunal Federal, como órgão atuante no combate à criminalidade, sendo inúmeras, como já dito, as extradições concedidas.

Em razão do modelo de contenciosidade limitada estabelecido no País, o Supremo Tribunal Federal não pode entrar na análise do mérito da questão que ensejou o pedido, pois, se assim o fizesse, estaria afrontando a soberania do outro Estado. A atuação da Corte se limita a avaliar a legalidade da concessão da extradição, conforme nossas leis internas ou normas estabelecidas em tratado internacional em vigor entre o Brasil e o Estado requerente. Portanto, um elevado número de concessões significa um efetivo combate à criminalidade pelo Supremo Tribunal Federal, na porção que lhe cabe no processo extradicional.

Além disso, outros fatores indicam uma postura ativa da Egrégia Corte Suprema quanto ao instituto da extradição no período analisado. Destaca-se, em especial, o retorno da obrigatoriedade de comutação de prisão perpétua em pena privativa de liberdade em até 30 anos, após quase 20 anos, com uma devida fundamentação que pauta-se pelas normas constitucionais e de Direitos Humanos.

$\mathrm{Na}$ sua atividade, em respeito aos tipos de crimes que analisam nos pedidos extradicionais, o STF procede ao estudo de cada caso, verificando, não só o tipo penal, mas o fato imputado ao indivíduo para examinar a existência, ou não, de dupla tipicidade. Como citado anteriormente, nos casos de estelionatos, em diversos países o nomen juris atribuído para este crime era muito distinto, mas, após o estudo dos Ministros, se concluiu pela identidade entre os tipos penais. 
Em outra forma de abordagem, quanto à periculosidade dos crimes examinados pelos Ministros, esta não é alta, e pelo contrário, a maioria envolve crimes com baixa ofensividade. Os tipos de crimes mais suscitados foram os crimes contra o patrimônio, em específico o de estelionato, mas os crimes de tráfico ilícito de entorpecentes e de drogas apresentaram também um número considerável.

As normas do Estatuto do Estrangeiro foram devidamente observadas, principalmente $o$ art. 76, que permite a concessão da extradição através da promessa de reciprocidade. O Supremo Tribunal Federal analisou os pedidos baseados nas promessas, atentando também para possíveis disparidades entre as respectivas legislações do país estrangeiro e a brasileira que impossibilitassem a promessa de reciprocidade. A Alemanha é um exemplo de nação que se utilizou deste tipo de procedimento de extradição, tendo obtido, na maioria das vezes, o êxito do pedido.

Outra evidência do detalhado exame da legalidade do pleito extradicional pela Corte Suprema, é o indeferimento de diversos crimes falimentares, em razão da regra particular de prescrição destes crimes no sistema jurídico brasileiro. Apontando a singularidade e procedendo ao devido cálculo, o Supremo Tribunal Federal fundamentou todos os pedidos indeferidos.

O Tribunal também observou as normas oriundas de seu Regime Interno, bem como a Súmula 421, que versa sobre a possibilidade de extradição ainda que o extraditando tenha família brasileira, refutando, assim, inúmeras defesas que pugnavam pelo indeferimento em razão do indivíduo ter filho(a), cônjuge ou companheiro(a) no Estado.

O perfil atual da nossa Corte Suprema, portanto, é aquele de um Tribunal que exerce devidamente a sua função, conforme lhe ditam as normas internas e internacionais, aprimorando a interpretação destas.

Sendo assim, resta evidente que, no tocante à esfera de atuação do Supremo Tribunal Federal, este atua pelo devido combate à criminalidade em âmbito internacional. Ainda que de forma restrita, pelo modelo de contenciosidade limitada, que não permite a Corte adentrar no mérito da questão, o Tribunal concedeu a maior parte dos pedidos, não se atendo à questão da justiça, ou não, da concessão. 
A principal conclusão a que chegamos é que nossa Egrégia Corte Suprema aplica adequadamente o Direito Extradicional, e, consequentemente, em nada contribui para um perfil mítico de ser o Brasil um país leniente com criminosos estrangeiros que aqui venham homiziar-se. Ao contrário, como demonstrado pela maioria dos casos analisados da Corte, a tendência tem sido, o decisum favorável à concessão da extradição.

\section{REFERÊNCIAS}

BRASIL. Constituição. Senado Federal, 1988.

. Estatuto do Estrangeiro, Lei no 6.815, de 19 de agosto de 1980.

CAHALI, Yussef Said. Estatuto do Estrangeiro. $2^{\text {a }}$ Ed. São Paulo: Editora Revista dos Tribunais, 2010.

CARNEIRO, Camila Tagliani. A Extradição no Ordenamento Jurídico Brasileiro. São Paulo: Memória Jurídica Editora. 2002

DOLINGER, Jacob. Direito Internacional Privado: Parte Geral. 10 ed. Rio de Janeiro: GEN Forense, 2011.

MELLO, Celso D. de Albuquerque. Curso de Direito Internacional Público. Volume 2. 13 ed. Rio de Janeiro: Renovar. 2001.

MINISTÉRIO DA JUSTIÇA. Procedimentos de extradição. Disponível em: < http://portal.mj.gov.br/>. Acesso em 02 nov. 2013

SUPREMO TRIBUNAL FEDERAL. Consulta jurisprudência. Disponível em <http:// http://www.stf.jus.br/portal/jurisprudencia/> . Acesso em: o2 abril 2013 .

TIBURCIO, Carmen. Temas de Direito Internacional. Rio de Janeiro: Renovar, 2006. 